\title{
Working
}

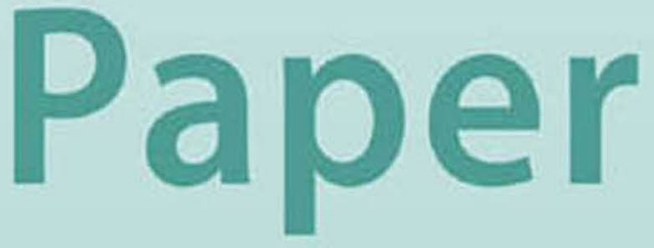




\section{Intertwined Sovereign and Bank Solvencies in a Model of Self-Fulfilling Crisis}

Gustavo Adler 


\title{
IMF Working Paper
}

Western Hemisphere Department

\section{Intertwined Sovereign and Bank Solvencies in a Model of Self-Fulfilling Crisis ${ }^{1}$ \\ Prepared by Gustavo Adler}

Authorized for distribution by Charles Kramer

July 2012

\section{This Working Paper should not be reported as representing the views of the IMF.} The views expressed in this Working Paper are those of the author(s) and do not necessarily represent those of the IMF or IMF policy. Working Papers describe research in progress by the author(s) and are published to elicit comments and to further debate.

\begin{abstract}
Large fiscal financing needs, both in advanced and emerging market economies, have often been met by borrowing heavily from domestic banks. As public debt approached sustainability limits in a number of countries, however, high bank exposure to sovereign risk created a fragile inter-dependence between fiscal and bank solvency. This paper presents a simple model of twin (sovereign and banking) crisis that stresses how this interdependence creates conditions conducive to a self-fulfilling crisis.
\end{abstract}

JEL Classification Numbers: E44, E51, E63.

Keywords: Banking crisis, sovereign debt crisis, twin crisis.

Author’s E-Mail Address: gadler@imf.org

\footnotetext{
${ }^{1}$ A previous version of this paper was published as part of my $\mathrm{PhD}$ dissertation at UCLA, under the title "Essays on Financial Crises - Sources of Public Financing and Financial Instability". I am very grateful to Carlos Végh for his feedback, and Charles Kramer, Luis Cubeddu and seminar participants at UCLA's Economics Department for their useful comments.
} 


\section{Contents}

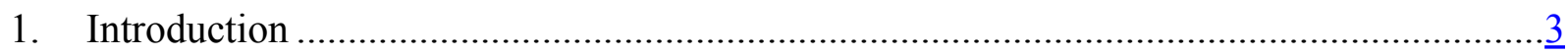

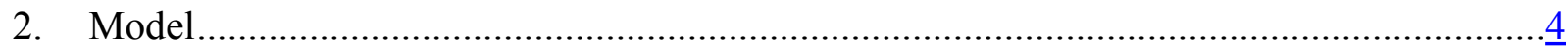

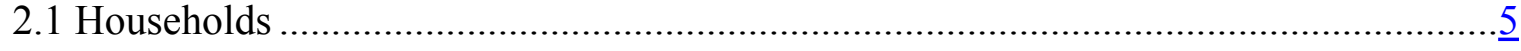

2.2 Domestic Financial Intermediaries.................................................................. $\frac{6}{9}$

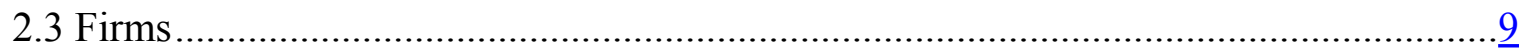

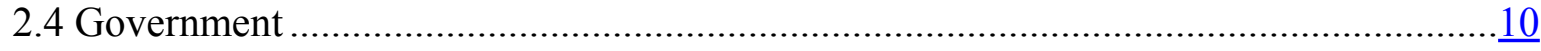

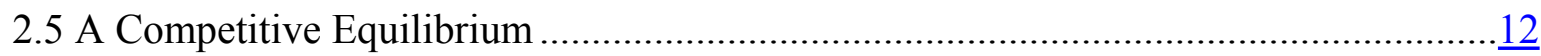

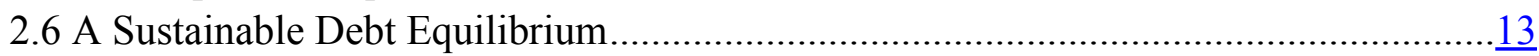

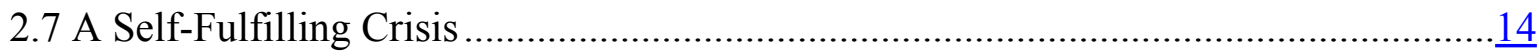

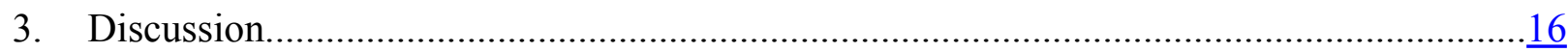

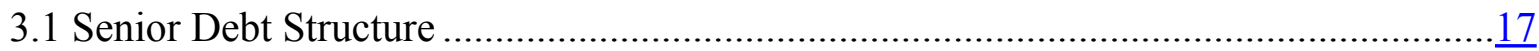

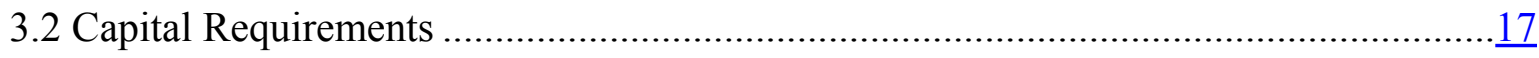

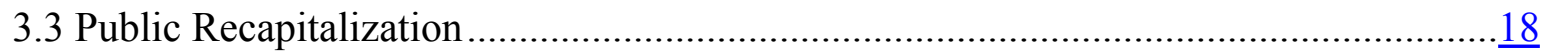

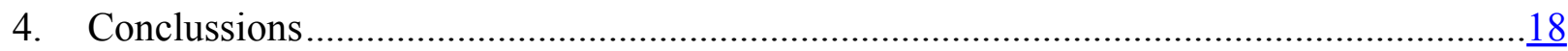

Figures

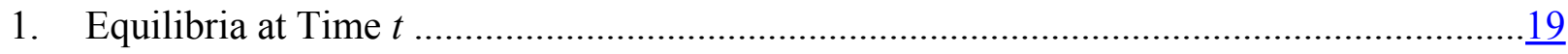

2. Equilibria with Different Levels of Domestic Debt .........................................................

3. Probability of Crisis and Effect on Prices, Private Credit and Output ...................................

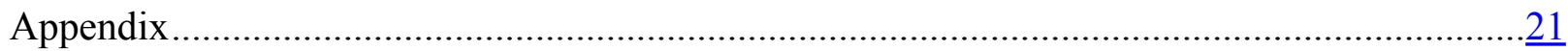

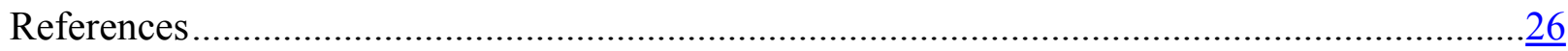




\section{Introduction}

Past crises in emerging market economies, and ongoing ones in advanced economies, have shown that large fiscal financing needs are often met by borrowing heavily from domestic commercial banks, particularly as foreign financing dries up. This was the case in the crises of Russia (1998), Brazil (1999), Turkey (2000), Argentina (2001) and more recently in a number of European countries. In many instances, domestic financing was considered as a relatively safe form of funding, not subject to rollover risks associated to foreign capital, in part because coordination problems could be overcome by using regulatory policy tools on domestic financial institutions. ${ }^{2}$

In many of these countries, however, commercial banks are also the main source of private credit (to households and corporates), especially where capital markets are underdeveloped and direct access to foreign financing is limited. This paper argues that, in these economies, a high bank exposure to sovereign risk gives raise to a fragile interdependence between fiscal and bank solvency and so the possibility of a self-fulfilling crisis. It presents a simple model showing that, if domestic financial intermediaries hold government debt in amount above some threshold value (which depends on banks' initial level of capital), there exist more than one equilibrium and therefore the economy becomes vulnerable to market expectations (self-fulfilling crisis). This follows from the fact that, as mentioned before, the fiscal solvency depends on the strength of the banking system (through the credit channel) and the value of banks capital itself depends on expectations of fiscal solvency as they hold government securities in their portfolios.

The interplay between sovereign and banks have been subject of previous studies, although from different angles. An important strand of the literature, following the Asian crisis, have stressed the role of bailout guarantees in creating incentives for financial institutions to over-expose to risk, including through currency mismatches, and creating contingent liabilities to the government. In this paper, we overlook at the role of government guarantees showing that even when agents fully internalize the risks associated to investing in government securities, the multiplicity of equilibria can occur as the result of an interdependence between the fiscal solvency and the financial system solvency, through the credit channel. In this case, the exposure of banks to sovereign risk does not create a contingent liability but a contingent fiscal revenue shortage.

The role of domestic banks as a mayor lender to the government has also been studied by Rodriguez (1992) and Druck (1999) among others, although they have not focused

\footnotetext{
${ }^{2}$ For example, Argentina relied on a number of regulatory measures to prevent banks from reducing their sovereign exposures during the 2001 financial crisis.
} 
on its contribution to the financial fragility of the system, or its role in financial crises. More broadly, within the literature on financial crises, Buiter (1987), Calvo (1998), Flood et al (1996), Kumhof (1998) and Corsetti and Mackowiak (2002) have recognized the role of domestic borrowing during times of financial turmoil as an important policy instrument, but they have mainly focused on the effect of currency denomination and maturity on the dynamics of the crisis, overlooking the role of the source of funding and the possibility of self-fullfilling crises. Among them, only Calvo suggests the possibility of multiple equilibria deriving from domestic debt, although arising from a coordination problem in rolling over short term instruments.

A more recent strand of literarure has also paid attention to the interplay between banks and sovereign debt, but focusing on foreign rather than domestic banks (as these papers studied primarily how the link between sovereigns and foreign banks gave rise to an international tramission channel of business cycle fluctuations. ${ }^{3}$

The paper is organized as follows: Section 2 develops a model of financial crisis, with a focus on the role of domestic borrowing as a source of financial instability. Section 3 discusses some debt and regulatory arrangements that can rule out this source of financial fragility. Section 4 concludes with the key takeaways.

\section{Model}

Consider a small open economy populated by a continuum of identical households. There is an homogeneous tradable good, which production is carried out by specialized firms which require credit in advance from local banks for their production activities. Financial intermediation is carried out by domestic banks which borrow from external markets in order to lend to the domestic private sector and the government. ${ }^{4}$ Banks are assumed to face borrowing constraints in external markets, such that the amount the are able to borrow depends on the value of their capital (net worth). This can also be thought of as regulatory limits on leverage.

There is an stochastic public signal s, unrelated to economic fundamentals, that at time $t$ can take value 1 or 0 according to the following transition probability matrix:

\footnotetext{
${ }^{3}$ See, for example, Guerrieri et al (2012), Mendoza and Quadrini (2010), Kollmann et al (2011), Kalemli-Ozcan et al (2011), Kamber and Thonissen (2012) and Ueda (2012).

${ }^{4}$ The implicit assumption is that domestic financial intermediaries have an informational advantage in providing credit to local firms so that firms do not borrow directly from external markets. The literature on banking has largely discussed this informational role of banks. See, for example, Leland and Pyle (1977), Diamond (1984) and Allen (1990).
} 


$$
P=\left[\begin{array}{cc}
(1-q) & 0 \\
q & 1
\end{array}\right]
$$

That is : $p\left(s_{t+1}=1 \mid s_{t}=1\right)=1$ and $p\left(s_{t+1}=1 \mid s_{t}=0\right)=q$. So, define $t=T$ as the time at which the signal takes value $\mathrm{s}=1$ for first time, it follows that for all $t>T$ there is no further uncertainty in the economy. ${ }^{5}$

The government levies taxes on firms' profits (value added tax) and borrows both from external and domestic markets in order to finance public spending. Domestic and external borrowing are assumed to be carried out in terms of units of the consumption good (real debt). Thus, in absence of currency, the distinction between domestic and foreign debt refers hereonwards to the source of funds (creditor). Furthermore, domestically issued debt is assumed to be an imperfect substitute for external debt, so that foreign investors do not invest in these securities ${ }^{6}$.

\subsection{Households}

Households derive utility from consuming a tradable good according to the following lifetime utility function:

$$
W_{0}=E_{0} \sum_{t=0}^{\infty} \beta^{t} u\left[c\left(s_{t}\right)\right]
$$

where $\beta$ is the discount factor, $c_{t}$ denotes consumption and $s_{t}$ denotes the state of nature at time t.They are assumed to have access to foreign (risk free) bonds as a saving instrument, that yields a return $r$ in each period. They own all firms in the economy, including financial intermediaries and productive firms, from which they receive dividends $d_{t}^{b}$ and $d_{t}^{f}$ respectively. Their budget constraint is thus given by:

$$
c_{t}\left(s_{t}\right)+k_{t}^{h}\left(s_{t}\right)=k_{t-1}^{h}(1+r)+d_{t}^{b}\left(s_{t}\right)+d_{t}^{f}\left(s_{t}\right)+g_{t}
$$

where $c_{t}$ denotes consumption, $k_{t}^{h}$ are holdings of foreign bonds and $g_{t}$ denotes government transfers.

\footnotetext{
${ }^{5}$ While the public signal is unrelated to economic fundamentals, as it is usual in the literature of self-fulfilling crisis, this signal will allows to specify an equilibrium in which agents coordinate actions by observing this signal. The coordination game is not explicitly specified, in order to keep the model simple. However, it is not difficcult to set up a bidding game on government securities to show that coordination problems arise when the value of this securities for each agent depends on the value at which other agents trade these securities.

${ }^{6}$ Market segmentation is not essential to the results of the paper, as explain in detail later, but allows to simplify the model.
} 
The household optimization problem consists therefore in choosing contingent paths for $\left\{c_{t}, k_{t}^{h}\right\}$ that maximize (2) subject to (3) and the No Ponzi Game condition $\lim _{t \rightarrow \infty}\left[\frac{E_{0} k_{t}^{h}}{(1+r)^{t}}\right] \geq$ 0 , taking $k_{0}$ and the stochastic process $\left\{d_{t}^{b}, d_{t}^{f}, g_{t}\right\}$ as given.

Assuming that $\beta(1+r)=1$ (to ensure the existence of a steady state) the first order conditions that characterize the solution to this problem are simply given by:

$$
\begin{aligned}
u^{\prime}\left[c_{t}\left(s_{t}\right)\right] & =E_{0}\left\{u^{\prime}\left[c_{t+1}\left(s_{t+1}\right)\right]\right\} \\
\lim _{t \rightarrow \infty}\left[\frac{E k_{t}^{h}}{(1+r)^{t}}\right] & =0
\end{aligned}
$$

Equation (4) is the usual Euler equation that defines the optimal path of consumption; and equation (5) is the usual transversality condition which follows from the No Ponzi game condition.

Solving recursively equation (3) and using the transversality condition (5) yields the household's intertemporal budget constraint:

$$
E_{0} \sum_{t=0}^{\infty} \frac{c_{t}(s)}{(1+r)^{t}}=k_{0}(1+r)+E_{0} \sum_{t=0}^{\infty} \frac{\left[d_{t}^{f}(s)+d_{t}^{f}(s)+g_{t}(s)\right]}{(1+r)^{t}}
$$

In a perfect foresight environment, from equation (4) follows that the path of consumption is flat over time $\left(c_{t}=\bar{c}\right)$ and from equation (6) follows that $\bar{c}=r k_{0}^{h}+$ $r \sum_{t=0}^{\infty}\left[d_{t}^{f}+d_{t}^{f}+g_{t}\right] /(1+r)^{t}$.

\subsection{Domestic Financial Intermediaries}

Domestic banks borrow from external markets and lend either to the government or to the private sector. Their optimization problem entails maximizing the present value of dividends paid to the households:

$$
V_{0}^{b}=E_{0} \sum_{t=0}^{\infty} \frac{d_{t}^{b}\left(s_{t}\right)}{(1+r)^{t}}
$$

Define $w_{t}^{b}$ as the bank's capital (net worth) at time $t$, after paying dividends $\left(d_{t}^{b}\right)$. Then, the bank's balance sheet is given by:

$$
w_{t}^{b}\left(s_{t}\right)=l_{t}^{b}+k_{t}^{b}+z_{t}\left(s_{t}\right) b_{t}^{b}
$$

where $b_{t}^{b}$ denotes holdings of domestic government bonds (with market value $z_{t}$ ); $l_{t}^{b}$ denotes loans to the private sector and $-k_{t}^{b}$ denotes borrowing from abroad. From the 
definition of net worth, the bank's budget constraint can be written as:

$$
w_{t}^{b}(s)=\left[z_{t}(s)+x_{t}(s)\right] b_{t-1}^{b}+l_{t-1}^{b}\left(1+r_{t-1}^{l}\right)+k_{t-1}^{b}(1+r)-d_{t}^{b}(s)
$$

And rearranging this equation yields an expression for time $t$ dividends:

$$
d_{t}^{b}(s)=\left[z_{t}(s)+x_{t}(s)\right] b_{t-1}^{b}+l_{t-1}^{b}\left(1+r_{t-1}^{l}\right)+k_{t-1}^{b}(1+r)-w_{t}^{b}(s)
$$

Financial intermediaries can be credit constrained in certain states of nature, with their borrowing limit depending on the value of their capital:

$$
-k_{t}^{b} \leq \gamma w_{t}^{b}
$$

where $\gamma>0$ is a parameter that reflects their ability to borrow agains its capital (collateral). This constraint can also be written as $l_{t}^{b}+z_{t} b_{t}^{b} \leq(1+\gamma) w_{t}^{b}$ by using the balance sheet identity, highlighting the link between the value of government bond holdings $\left(z_{t} b_{t}^{b}\right)$ and lending to the private sector, for a given level of capital $\left(w_{t}^{b}\right)$. In order to simplify the dynamics of the economy, it is assumed that banks pass all contempareouns profits to their shareholders and cannot be recapitalized by issuing equity (negative dividends in the model) in the event of a fall in their net worth:

$$
d_{t}^{b}=\max \left[0, \pi_{t}^{b}\right]
$$

or

$$
d_{t}^{b} \geq \pi_{t}^{b} ; \quad d_{t}^{b} \geq 0
$$

where $\pi_{t}^{b}$ denotes time t banks's profits ${ }^{7}$. This condition implies that financial intermediaries cannot accumulate capital over time.

The financial intermediary optimization problem consists therefore in choosing stochastic processes for $\left\{k_{t}^{b}, l_{t}^{b}, b_{t}^{b}, d_{t}^{b}\right\}$ to maximize equation (7) subject to (8), (10), (11) and (13), taking the stochastic processes $\left\{z_{t}, x_{t}, r_{t}^{l}\right\}$ and $w_{0}^{b}$ as given.

Define $t=T$ as the period in which a crisis take place. Then, the first order conditions that characterize banks's maximization problem are given by:

${ }^{7}$ Banks profits are given by:

$$
\begin{aligned}
\pi_{t}^{b} & =\left(w_{t}^{b}+d_{t}^{b}\right)-w_{t-1}^{b} \\
& =\left[z_{t}+x_{t}-z_{t-1}(1+r)\right] b_{t-1}^{b}+l_{t-1}^{b}\left(r_{t-1}^{l}-r\right)+w_{t-1}^{b} r
\end{aligned}
$$




$$
\begin{aligned}
{\left[\gamma w_{t}^{b}\left(s_{t}\right)+k_{t}\right]\left[\frac{r_{t}^{l}\left(s_{t}\right)-r}{(1+r)}\right] } & =0 \\
d_{t}^{b}\left(s_{t}\right)\left[\lambda_{t}\left(s_{t}\right)\right] & =0 \\
{\left[d_{t}^{b}\left(s_{t}\right)-\pi_{t}^{b}\left(s_{t}\right)\right]\left[\mu_{t}\left(s_{t}\right)\right] } & =0 \\
\frac{E_{t}\left\{\left[z_{t+1}\left(s_{t+1}\right)+x_{t+1}\left(s_{t+1}\right)\right]\left[1+\lambda_{t+1}\left(s_{t+1}\right)\right]\right\}}{\left[1+r_{t}^{l}\left(s_{t}\right)\right] \cdot E_{t}\left\{1+\lambda_{t+1}\left(s_{t+1}\right)\right\}} & =z_{t}\left(s_{t}\right)
\end{aligned}
$$

where $\lambda_{t}\left(s_{t}\right)$ is the lagrange multiplier associated to the constraint $\left(d_{t}^{b} \geq 0\right)$ at time $t$, and it is equal to:

$$
\lambda_{t}\left(s_{t}\right)= \begin{cases}0 & \text { if } t \neq T \\ \sum_{j=0}^{\infty}\left[\frac{(1+\gamma)\left(r_{t+j}^{l}-r\right)}{(1+r)^{j}}\right] & \text { if } t=T\end{cases}
$$

and $\mu_{t}\left(s_{t}\right)$ is the lagrange multiplier associated to the constraint $\left(d_{t}^{b} \geq \pi_{t}^{b}\right)$ at time $t$, and it is equal to:

$$
\mu_{t}\left(s_{t}\right)= \begin{cases}E_{t} \sum_{j=1}^{\infty}\left[\frac{\lambda_{t+j}(s)}{(1+r)^{j-1}}\right] & \text { if } t \neq T \\ 0 & \text { if } t=T\end{cases}
$$

Note first from equations (17) and (18) that the constraints associated to $\lambda_{t}(s)$ and $\mu_{t}(s)$ cannot bind at the same time. From equation (16) it is clear that the borrowing constraint binds only when the domestic interest rate is higher than the international interest rate $\left(r_{t}^{l}>r\right)$.

Equations (17) and (18) implicitly define the value of dividends paid at time t, and also the path of bank's net worth. This can be seen by re-writting equation (18) as:

$$
\left[w_{t-1}^{b}-w_{t}^{b}\right] \mu_{t}=0
$$

and equation (17) as:

$$
\left[w_{t-1}^{b}+\pi_{t}^{b}-w_{t}^{b}\right] \lambda_{t}=0
$$

It follows that if $\pi_{t}^{b}>0$, only (18) can bind and therefore $w_{t-1}^{b}=w_{t}^{b}$. This corresponds to the 'good' $(\mathrm{s}=0)$ state of nature, and financial intermediaries make positive profits. On the other hand, if profits are negative $\left(\pi_{t}^{b}<0\right)$, only (17) can bind and therefore $w_{t}^{b}=w_{t-1}^{b}+\pi_{t}^{b}<w_{t-1}^{b}$. This will be the case when a bad shock takes place. As a result, the path of bank's net worth can be characterized by the following difference equation: 


$$
w_{t}^{b}=w_{t-1}^{b}+\min \left[0, \pi_{t}^{b}\right]
$$

From (21) it is clear that before a crisis takes place the constraint $d_{t}^{b} \geq \pi_{t}^{b}$ binds as long as $E_{t}\left(r_{t+j}^{l}-r\right)>0$ for any $j>0$. That is, if the event of a crisis associated to a credit crunch has positive probability, then, $d_{t}^{b} \geq \pi_{t}^{b}$ for all $t<T$ even if borrowing constraints are not binding.

Finally notice that equation (19) gives the pricing formula for domestic government bonds. This equation can be re-written as:

$$
E_{t}\left[\frac{z_{t+1}+x_{t+1}}{z_{t}}-1\right]=r+\left(r_{t}^{l}-r\right)-\frac{\operatorname{cov}\left[z_{t+1}+x_{t+1}, 1+\lambda_{t+1}\right]}{E_{t}\left[1+\lambda_{t+1}(s)\right]}
$$

The left-hand side of this equation denotes the expected return on government bonds. The first term in the right-hand side is the risk free rate; the second term is the liquidity premium which can exist if the borrowing constraint is binding; and the last term is the risk premium, which is determined by the covariance between government bond prices (and interest payments) and the domestic interest rates (which reflect the need for resources when borrowing constraints bind). Although financial intermediaries are risk neutral, they invest in government bonds only if compensated for the volatility of their return. ${ }^{9} 10$

\section{$2.3 \quad$ Firms}

Firms in the real sector produce an homogeneous tradable good using a technology with decreasing returns with the following functional form:

$$
y_{t}=f\left(I_{t}\right)=I_{t}^{\sigma}
$$

${ }^{8}$ Note that in the event of a bad shock $\lambda_{t}=\sum_{j=0}^{\infty}\left[\frac{(1+\gamma)\left(r_{t+j}^{l}-r\right)}{(1+r)^{j}}\right]$, which is a measure of the scarcity of funds in the economy in the periods following a bad shock (crisis).

${ }^{9}$ This can be seen as a version of the CAPM derived from a model of financial frictions, where agents require a premium for volatility to the extent that the behavior of government bond prices exacerbates liquidity constraints.

${ }^{10}$ If the risk premium term in equation (25) is positive, banks would hold positive amounts of government liabilities in equilibrium only if: i) the country faced an upward sloping supply of funds in external markets or ii) external investors saw domestically issued bonds as imperfect substitutes for international bonds (and did not invest in them). As discussed before, we assume the second case for simplicity. 
with $\sigma<1$. Investment $\left(I_{t}\right)$ is recovered, undepreciated, after production takes place. Firms require credit in advance $\left(l_{t}\right)$ from the domestic baking system in order to invest in inputs needed for next period production.

$$
I_{t} \leq l_{t}
$$

They seek to maximize their market value, given by the present expected value of dividends.

$$
V_{0}^{f}=E_{0} \sum_{t=0}^{\infty} \frac{d_{t}^{f}(s)}{(1+r)^{t}}
$$

They pay taxes on profits, which they pass immediately to the shareholders in the form of dividends $\left(d_{t}^{f}=\pi_{t}^{f}\right)$. Then, defining $\tau$ as the fixed tax rate, firms' net profits can be expressed as:

$$
\pi_{t}^{f}=(1-\tau)\left[\left(I_{t-1}\right)^{\sigma}-\left(r_{t-1}^{l}\right) l_{t-1}\right]
$$

The firm's problem consists thus in choosing optimal paths for $\left\{I_{t}, l_{t}\right\}$ to maximize equation (29) subject to (27). The first order condition for the firm's maximization problem is threfore:

$$
\sigma\left(l_{t}\right)^{\sigma-1}=\left(r_{t}^{l}\right)
$$

which implicitly defines the demand for loans as a function of the corresponding interest rate. Under this specification profits can be expressed as:

$$
\pi_{t}^{f}=(1-\tau)(1-\sigma)\left(l_{t-1}\right)^{\sigma}=(1-\tau)(1-\sigma) y_{t}
$$

It follows that fiscal revenues are linearly linked to the level of domestic output, and so the supply of credit. Finally note that if the domestic interest rate is equal to the international interest rate (borrowing constraints do not bind), output reaches its maximum ("full employment') level, which we denote as $\bar{y}$, at:

$$
\bar{y}=\left[\frac{r}{\sigma}\right]^{\frac{\sigma}{\sigma-1}}
$$

\subsection{Government}

Taxes are levied on firms' profits in order to finance expenditure $(g)$ and the initial debt position. The government has access to three types of securities through which it can finance itself: short term (1-period) external debt $(v)$ and long term external and domestic borrowing ( $b^{*}$ and $b$ respectively), both of which take the form of perpetuities that pay $x_{t}$ units of consumption good in each period. 
The choice of long term liabilities in the setup of the model is deliberate, aiming to stress the fact that the absence of short term sovereign debt does not rule out liquidity problems when domestic banks intermediate these securities.

The government budget constraint is given by:

$$
\Gamma_{t}+v_{t}+z_{t} b_{t}+z_{t}^{*} b_{t}^{*}=v_{t-1}(1+r)+z_{t} b_{t-1}+z_{t}^{*} b_{t-1}^{*}+x_{t} b_{t-1}+x_{t} b_{t-1}^{*}+g_{t}
$$

where $\Gamma_{t}$ denotes tax revenues; $z_{t}\left(z_{t}^{*}\right)$ denotes the market price of domestic (external) government bonds $b_{t}\left(b_{t}^{*}\right) ; v_{t}$ denotes short term external obligations and $g_{t}$ denotes expenditure in the form of transfers to the households. Notice that we have assumed that $x_{t}^{*}=x_{t}$, that is domestic and external investment receive equal treatment. In section 3 we discuss how results change if there is a differential treatment (seniority structure).

Expenditure is assumed to be constant over time, as well as the tax rate on firms' profits. This assumption is essential since implies that in case of a crisis associated to a fall in fiscal revenues, the government is unable to alter its spending plans in order to offset the fall in revenues and preserve its pre-crisis fiscal position. ${ }^{11}$

The tax rate and the level of government expenditure are set as to balance the initial budget, fully paying interests on the existing stock of debt (as long as a crisis does not take place $)^{12}$ :

$$
[\bar{\Gamma}-g]=r\left(b+b^{*}\right)
$$

Furthermore it is assumed that the government honors its liabilities as long as it has sufficient resources (there is no moral hazard in the model). It follows that path of interest payments $\left\{x_{t}\right\}$ is given by:

$$
x_{t}=\left[\begin{array}{ll}
r & \text { if } t \leq T \\
\theta r & \text { if } t>T
\end{array}\right.
$$

where $\theta<1$ denotes the recovery ratio in the event of a crisis that affects fiscal solvency (which, it at all, would take place at $t=T$ ).

Assume without loss of generality that the government does not issue new long term debt $\left(b_{t}=b_{t+1}, b_{t}^{*}=b_{t+1}^{*}\right)$ beyond the initial stock. Then, solving difference equation (33) and imposing the transversality condition $\left[\lim _{t \rightarrow \infty} E\left(q_{t}\right)=0\right]$ yields the government intertemporal budget constraint:

\footnotetext{
${ }^{11}$ Both first ans third generation models of currency crisis share this feature. A more recent literature has focused on the strategic behavior of the government regarding fiscal adjustment and sovereign debt repayment, although in a different setting. See, for example, Arellano et al (2012) and Conesa and Kehoe (2011).

${ }^{12}$ The initial stock of short term debt is equal to zero: $q_{0}=0$.
} 


$$
E_{t} \sum_{j=0}^{\infty} \frac{\left[\Gamma_{t+j}-g\right]}{(1+r)^{j}}=\left(b+b^{*}\right) E_{t} \sum_{j=0}^{\infty} \frac{\left[x_{t+j}\right]}{(1+r)^{j}}
$$

Furthermore, notice that from equation (35) and (36) follows that in the event of a crisis $x_{T+1}$ takes the value:

$$
x_{T+1}=\frac{r}{(1+r)[\bar{\Gamma}-g]} \sum_{j=0}^{\infty} \frac{\left[\Gamma_{T+j}-g\right]}{(1+r)^{j}}
$$

As it is clear from the last equation, a fall in fiscal revenues must be associated to a fall in interest payments on public liabilities; that is, a sovereign default.

Finally if the government faces a perfectly elastic supply of funds in external markets, then the market price of external debt is given by:

$$
z_{t}^{*}=\frac{E_{t}\left[z_{t+1}^{*}+x_{t+1}\right]}{(1+r)}=E_{t} \sum_{j=0}^{\infty} \frac{\left[x_{t+j}\right]}{(1+r)^{j}}
$$

Notice, from equation(19), that domestic and external bonds are priced differently, as market are segmented. The two securities are imperfect substitutes and foreign investors do not invest in domestically issued securities.

\subsection{A Competitive Equilibrium}

A competitive equilibrium in this economy is given by a set of stochastic processes for quantities $\left\{c_{t}, k_{t}^{h}, b_{t}^{b}, l_{t}^{b}, k_{t}^{b}, l_{t}^{f}, d_{t}^{b}, d_{t}^{f}, x_{t}, g_{t}\right\}$ and prices $\left\{r_{t}^{l}, z_{t}, x_{t}\right\}$ such that: i) the stochastic processes $\left\{c_{t}, k_{t}^{h}\right\}$ solve the households' maximization problem given $\left\{d_{t}^{b}, d_{t}^{f}, g_{t}\right\}$; ii) $\left\{d_{t}^{b}, l_{t}^{b}, b_{t}^{b}, k_{t}^{b}\right\}$ solve financial intermediaries' maximization problem given $\left\{r_{t}^{l}, z_{t}, x_{t}\right\}$; iii) $\left\{l_{t}^{f}\right\}$ solve firms' maximization problem given $\left\{r_{t}^{l}\right\}$; iv) the government intertemporal budget constraint holds; and v) markets clear: $l_{t}^{b}=l_{t}^{f} ; b_{t}^{b}=b$.

We can build a simple system of nonlinear equations that characterize the equilibrium path of this economy.

Combining equations (16) and (30) yields :

$$
y_{t}= \begin{cases}\bar{y} & \text { if } \bar{l}+z_{t-1} b \leq(1+\gamma) w_{t-1}^{b} \\ {\left[(1+\gamma) w_{t-1}^{b}-z_{t-1} b\right]^{\sigma}} & \text { if } \bar{l}+z_{t-1} b>(1+\gamma) w_{t-1}^{b}\end{cases}
$$

From (36) and (37) we know: 


$$
x_{t}=\left\{\begin{array}{rr}
r & \text { if } t \leq T \\
\frac{r}{(1+r)[\bar{\Gamma}-g]} \sum_{j=0}^{\infty} \frac{\left[(1-\sigma) y_{T+j}-g\right]}{(1+r)^{j}} \quad \text { if } t \leq T
\end{array}\right.
$$

From equations (26) and (30) we know that domestic interest rates are linked to output by $r_{t}^{l}=\sigma y_{t+1}^{\frac{\sigma-1}{\sigma}}$. Then equation (20) can be written as:

$$
\lambda_{t}\left(s_{t}\right)= \begin{cases}0 & \text { if } t \neq T \\ \sum_{j=0}^{\infty}\left[\frac{(1+\gamma)\left(\sigma y_{t+j}^{\frac{\sigma-1}{\sigma}}-r\right)}{(1+r)^{j}}\right] & \text { if } t=T\end{cases}
$$

And the path of banks' net worth and the pricing formula for domestic bonds, as before, it is given by:

$$
\begin{gathered}
\frac{E_{t}\left\{\left[z_{t+1}\left(s_{t+1}\right)+x_{t+1}\left(s_{t+1}\right)\right]\left[1+\lambda_{t+1}\left(s_{t+1}\right)\right]\right\}}{\left[1+r_{t}^{l}\left(s_{t}\right)\right] \cdot E_{t}\left\{1+\lambda_{t+1}\left(s_{t+1}\right)\right\}}=z_{t}\left(s_{t}\right) \\
w_{t}^{b}=w_{t-1}^{b}+\min \left\{0, \pi_{t}^{b}\right\}
\end{gathered}
$$

Finally, define $h_{t}\left(z_{t}^{*}\right) \equiv k_{t}^{h}+k_{t}^{b}+q_{t}-z_{t}^{*} b_{t}^{*}$ as the market value of the net external position of the country at time t. Then, combining equations (3), (9), (8) and (33) yields the resource constraint of the economy:

$$
h_{t}=h_{t-1}(1+r)+\left[z_{t}^{*}+x_{t}^{*}-z_{t-1}^{*}(1+r)\right] b_{t-1}^{*}+\left[f\left(l_{t-1}\right)+l_{t-1}-l_{t}\right]-c_{t}
$$

From here on it will be assumed (without loss of generality) that $g_{t}=0$ for all $t$ so that revenues are simply used to repay government liabilities; and that initial bank's net worth is high enough so that borrowing constraints do not bind in normal times (before crisis) and therefore the economy is in full employment. That is, define $\bar{l}$ as the equilibrium level of domestic credit to full employment $\left(\bar{y}=\bar{l}^{\sigma}\right)$, then we assume:

Assumption: $b+\bar{l}<(1+\gamma) w_{0}^{b}$

\subsection{A Sustainable Debt Equilibrium}

Under assumption 1 there is an equilibrium in which the public signal is irrelevant and there is no crisis, that is sovereign debt is sustainable and domestic financial intermediaries suffer no loss in any state of nature. As a result output is at its maximum at all times.

To show this, simply consider a set of beliefs such that agents expect prices to be 
invariant with the state of nature:

$$
z_{t}(s=0)=z_{t}(s=1)
$$

That is, individual agents expect other agents not pay attention to the realization of the public signal and trade government securities at the same value in any state of nature. We can show that this is consistent with a (perfect foresight) equilibrium of this economy, where prices do not change with the state of nature and therefore beliefs are correct.

Proposition 1 Under assumption 1, there exists a 'sustainable debt' equilibrium with no default $[\theta(s)=1$ for all $s]$ and full production $\left[y_{t}(s)=\bar{y}\right.$ for all $\left.s\right]$. At the margin the source of public financing is irrelevant.

The intuition is simple: If agents trust the government will be able to honor its liabilities, then, in equilibrium the market value of government liabilities is invariant to the state of nature. This implies that financial intermediaries cannot suffer any capital loss, no matter what is the level of public debt they hold in their portfolios. Therefore, if the economy is initially under full employment, it must continue in this way, as credit constraints do not bind at any time. Fiscal accounts remain balanced and no default takes place in equilibrium, which is consistent with the equilibrium beliefs. ${ }^{13}$

\subsection{A Self-fulfilling Crisis}

Notice however from equations (39) and (40) that the fiscal solvency and domestic banks' solvency are interdependent, and output is nonlinear in bank's net worth (and so in bond prices). This allows us to construct other equilibria satisfying the set of equations (39)(44) with stochastic prices for government bonds that change with the state of nature and therefore cause capital losses in the banking system.

Consider a set of beliefs such that $z_{t}(s=1)<z_{t}(s=0)$, that is, agents believe that in the event of a 'bad' realization of the public signal $(s=1)$ a crisis would take place and the government would be forced to default on its liabilities. It can be shown that under certain conditions there exist prices $z_{t}(s=0)>z_{t}(s=1)$ that satisfy these beliefs and are associated to a financial crisis with a fall in bank's net worth and a sovereign default.

\footnotetext{
${ }^{13}$ As the credit constraint does not bind and so there is no crowding out at the margin, the level of domestic borrowing in banks portfolio is irrelevant. In fact, domestic and external debt are priced equally: $z_{t}=z_{t}^{*}=1$ for all $t$.
} 
The equilibrium path of this economy is still characterized by the set of equations (39)-(44) but now we look for a solution with stochastic prices that satisfy $z_{t}(s=1)<$ $z_{t}(s=0)$. The following propositions characterize this equilibrium path and the conditions under which this 'crisis equilibrium' exists.

Proposition 2 The risk premium on domestic debt is positive $\left[\operatorname{cov}\left(z_{t}+x_{t}, \lambda_{t}\right)<0\right]$. Then, under assumption 1, the domestic and the international interest rate are equal $\left(r_{t}^{l}=r\right)$, and the economy is in full employment $\left(y_{t}=\bar{y}\right)$ for all $t \leq T$.

Proof. See appendix

This proposition shares the logic of the result of the previous section. Under assumption 1, credit constraints are initially non binding. Then, a long as financial intermediaries do not suffer a loss in the value of their portfolios, there is no contraction in their net worth and therefore there is no credit contraction. It follows that the equilibrium interest rate is $r_{t}^{l}=r$ for all periods before a crisis occur.

Proposition 3 There exists a threshold value $\bar{b} \equiv \frac{(1+r) w_{0}^{b}}{z_{t-1}(1+r)-r}$, such that, for any $t<T$, a necessary and sufficient condition for a crisis equilibrium to exist is that $b>\bar{b}$.

Proof. See appendix.

This proposition simply states that at any period $t$ a self-fulfilling crisis can occur if and only if the level of domestic borrowing is sufficiently high (above the threshold value $\bar{b}$ ). This can be shown by combining equations (39) and (40), as in Figure 1. Given the last period bond price $z_{t-1}$, equation (39) represents the credit supply schedule (CS) as a function of the current bond price $\left(z_{t}\right)$. On the other hand, equation (40) represents the fiscal constraint schedule (FC), linking the price of domestic bonds and output through the value of fiscal revenues. An equilibrium at time $t$ is therefore given by the intersection of both curves as shown in points A and B. Proposition 3 simply defines the condition for which a point $\mathrm{A}$ exist in the positive quadrant. As expected, this proposition shows that if domestic borrowing is too high (above the threshold level) a crisis can occur in equilibrium. This threshold value is increasing in the level of net worth of the banking system, as intuition would suggest, and decreasing in the previous period bond price. This follows from the fact that a high previous price implies a larger capital loss for each value of $z_{t}(s=1)$. Notice that in the extreme case in which the market assigns probability zero to a crisis $(q=0)$, then from equation (43) it is clear that $z_{t-1}=1$ and so the threshold value is $\bar{b} \equiv(1+r) w_{0}^{b}$. 
Corollary 4 There exists a threshold value $\underline{b}=(1+r) w_{0}^{b}$ such that if $b<\underline{b}$ a crisis cannot occur in this economy for any value of $q$. Also, in the limit case of $q=0$ ( realization $s=1$ has probability mass zero), $b>\underline{b}$ is a necessary and sufficient condition for a crisis equilibrium to exist.

This proposition presents a very intuitive result on the link between banks financial condition (measured by the net worth) and the amount of domestic government instruments. If the level of domestic borrowing is sufficiently low, relative to banks' net worth then a crisis equilibrium cannot exist. This follows from the fact that any fall in the market value of government liabilities can be "accommodated" with a loss in bank's net worth without resulting in a credit supply contraction (i.e., equation 16 does not bind). As a result output would not be affected by fluctuations in the market value of public liabilities and therefore fiscal accounts remain balance. This implies that a default cannot happen in equilibrium. In the limit case where the event of $s=1$ has probability mass equal to zero (is unexpected), then the threshold value becomes also an upper bound such that $b>\underline{b}$ is a sufficient condition for a crisis equilibrium to exist.

Finally, Figure $2^{14}$ shows how the equilibrium changes with the level of domestic debt when the equilibrium path is fully specified (that is, the pricing formula (43) is taken into account) and we consider cases with positive crisis probabilities $(q>0)$.

Notice that now the credit supply schedule is no longer linear in $z_{t}(s=1)$, precisely because under rational expectations $z_{t-1}$ is a function of $z_{t}(s=1)$. The figure shows three examples for different levels of domestic debt. In panel (a) the level of domestic borrowing is sufficiently low relative to bank's net worth so that a crisis cannot occur. Therefore, there is an unique equilibrium, which is the sustainable debt equilibrium. In panel (b) the level of domestic debt is sufficiently high so that a crisis equilibrium exists, and it is associated to a low bond price and a low level of output.

At last, Figure 3 shows how capital losses $\left(z_{t}-z_{t-1}\right)$, private lending and output vary with the probability of a crisis. As expected, as the probability increases the loss in net worth decreas and so private lending and output increases, reflecting the fact that agents anticipate the crisis and internalize the costs of a fall in the market value of government debt, therefore demanding risk compensation.

As Figure 3 makes clear, the crisis equilibrium emerges as a result of the existence of "excessive" domestic borrowing, precisely because domestic financial intermediaries play a key role in the provision of credit to the private sector and therefore in the creation of output. Domestic borrowing creates an interdependence between fiscal solvency and banks 'solvency that turns the economy vulnerable to market expectations about fiscal solvency. That is, a self-fulfilling crisis.

\footnotetext{
${ }^{14}$ Parameters used: $r=10 \% ; \sigma=.2 ; \gamma=6 ; w_{0}^{b}=4 ; q=1 \%$.
} 


\section{Discussion}

The model developed so far has three key features that make evident the possibility of alternative arrangements or policy responses that could rule out a self-fulfilling crisis equilibrium: (i) the passive role of the government in the repayment of foreign and domestic investors alike, (ii) the state-invariant collateral constraint faced by banks; and (iii) the inability of banks to recapitalize themselves in the event of a crisis. I discuss next how relaxing these assumption could potentially change the results of the model, although normally also bringing other 'side effects'.

\subsection{Senior Debt Structure}

A senior debt structure that subordinates external debt to domestic debt could insulate the domestic financial system from market concerns about fiscal solvency. ${ }^{15}$ It is simple to modify the model to incorporate this feature. Assume that domestic debt is senior to external debt, so that $x_{t}=r$ for all $t$ while $x_{t}^{*}$ still satisfies equation (35). It is straight forward to show that, under this assumption, domestic banks cannot suffer any capital loss in equilibrium and therefore, under assumption 1 , we know that $l_{t}=\bar{l}$ and $y_{t}=\bar{y}$ for all $t$. Since the economy is in full employment in every period and for all states of nature, the government budget constraint is satisfied with full debt repayment $(\theta=1)$, and so there is no crisis in equilibrium regardless of the state of nature. Such debt seniority structure may not need to be formal, and could simply result form the fact that defaulting on domestically-held instruments would carry higher costs than defaulting on externally-held instruments and so the government may give, ex post, preferential treatment to the former. This may, in fact, be a factor at play during times of financial distress, when domestic agents tend to increase their holdings of sovereign paper while foreign investors tend to reduce their positions. In this set up, since there is no uncertainty and there are no costs of defaulting on foreign investors, introducing a seniority structure comes at no cost. In a more realistic set up, however, a seniority structure could result in an increase in country risk premium (on foreign debt) as a smaller proportion of investors would bear all the burden of a fiscal insolvency.

\footnotetext{
${ }^{15}$ This was, arguably, the rationale behind the Argentinean domestic swap in 2001, where the government discriminated between domestic and external creditors precisely aiming to insulate the banking system from doubts about public debt sustainability. See Sturzenegger (2002) for a discussion of this case.
} 


\subsection{Capital Requirements}

The model presented above also assumed that banks faced exogenous collateral constraints $\left(-k_{t}^{b} \leq \gamma w_{t}^{b}\right)$. However, to the extent that these constraints result from regulatory requirements, one can also think of them as a policy tool that could allow to rule out a crisis equilibrium. This could, arguably, be achieved in two ways: (i) by introducing (ex-ante) capital requirements that are a function of the degree of exposure to the sovereign. That is, a risk weighting system that 'penalizes' excessive holdings of government paper, on account of the fact that the latter is a systemic agent in the economy, could de-incentivize banks' over-investment in these securities and so rule out a crisis equilibrium; (ii) by introducing (ex-post) flexibility in the regulatory framework such that capital requirements are relaxed ( $\gamma$ is increased) at times of distress. This would basically ensure that capital looses associated to a fall in the market value of sovereign debt would not lead to a credit crunch, as banks would be able to accommodate such losses without resorting to deleveraging, and so the crisis equilibrium would be ruled out. A similar outcome could be achieved by introducing a central bank that provides liquidity to banks that are credit constrained (due to insufficient capital). This, however, would allow to rule out the crisis equilibrium only if the collateral required by the central bank in order to provide liquidity is lower than that required by private agents (i.e., a relaxation of the overall collateral constraint).

\subsection{Public Recapitalization}

The assumption that private banks may not be able to find financing to restore capital in the event of a crisis is a realistic one. However, sovereigns often resort to public recapitalizations to limit the impact of capital looses on the financial sector as a whole and prevent a credit crunch. In the model presented here, this could be a possible solution that would rule out a self-fulfilling equilibria. There are, however, two important qualifications to this: (i) any public recapitalization would need to be at least fiscally neutral (i.e., the government could only invest in banks that are known to be profitable) otherwise the additional fiscal costs would still lead to a sovereign default in the model; (ii) while ex-post recapitalizations could help rule out a credit crunch, they could also, ex-ante, exacerbate moral hazard problems and lead to excessive risk taking (either by further increasing sovereign debt holdings or other risky assets in the economy).

In sum, any of these possible solutions that could help rule out a self-fulfilling crisis equilibrium suffer from important side effects that need to be assessed carefully. 


\section{Conclusions}

Large fiscal financing needs, both in advanced and emerging market economies, have often been met by borrowing heavily from domestic banks. As public debt approached sustainability limits in a number of countries, however, high bank exposure to sovereign risk created a fragile inter-dependence between fiscal and bank solvency. This paper presented a simple model of twin (sovereign and banking) crisis that stresses how this interdependence creates conditions conducive to a self-fulfilling crisis. While a number of possible arrangements could help break this dangerous inter-dependence, those do not appear to come free of side-effects. 
Figure 1. Equilibria at Time $t$

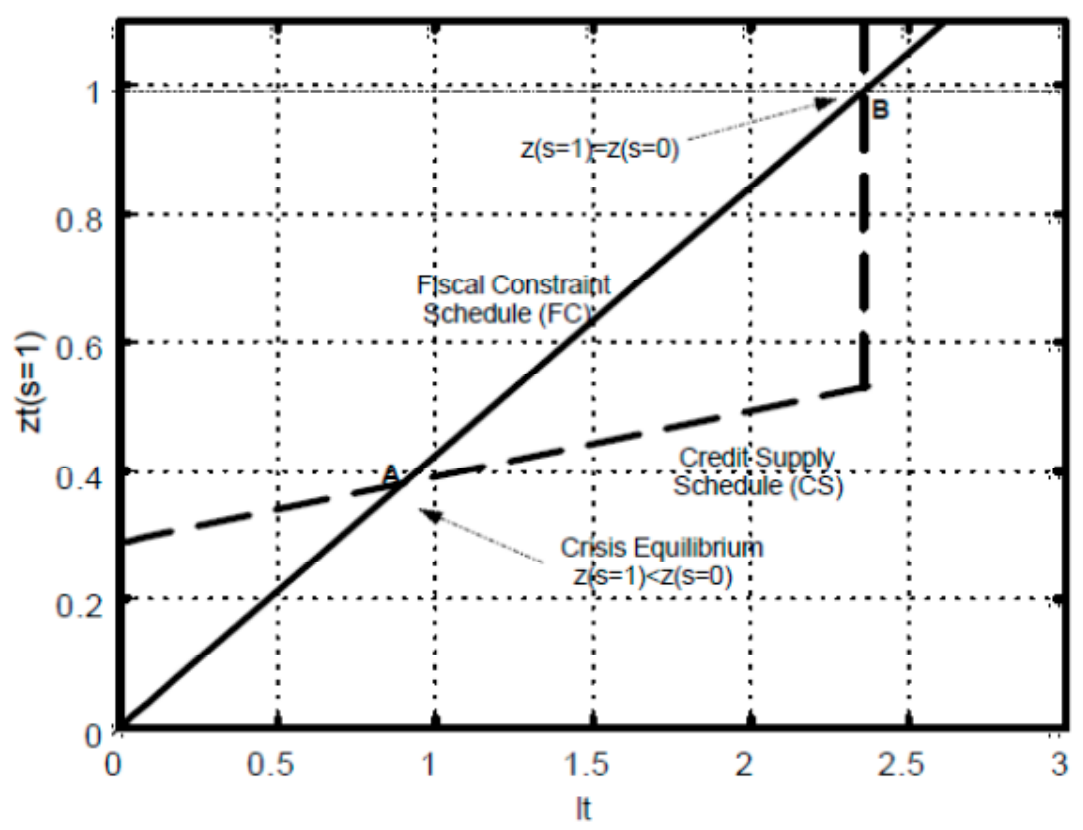

Figure 2. Equilibria with Different Levels of Domestic Debt
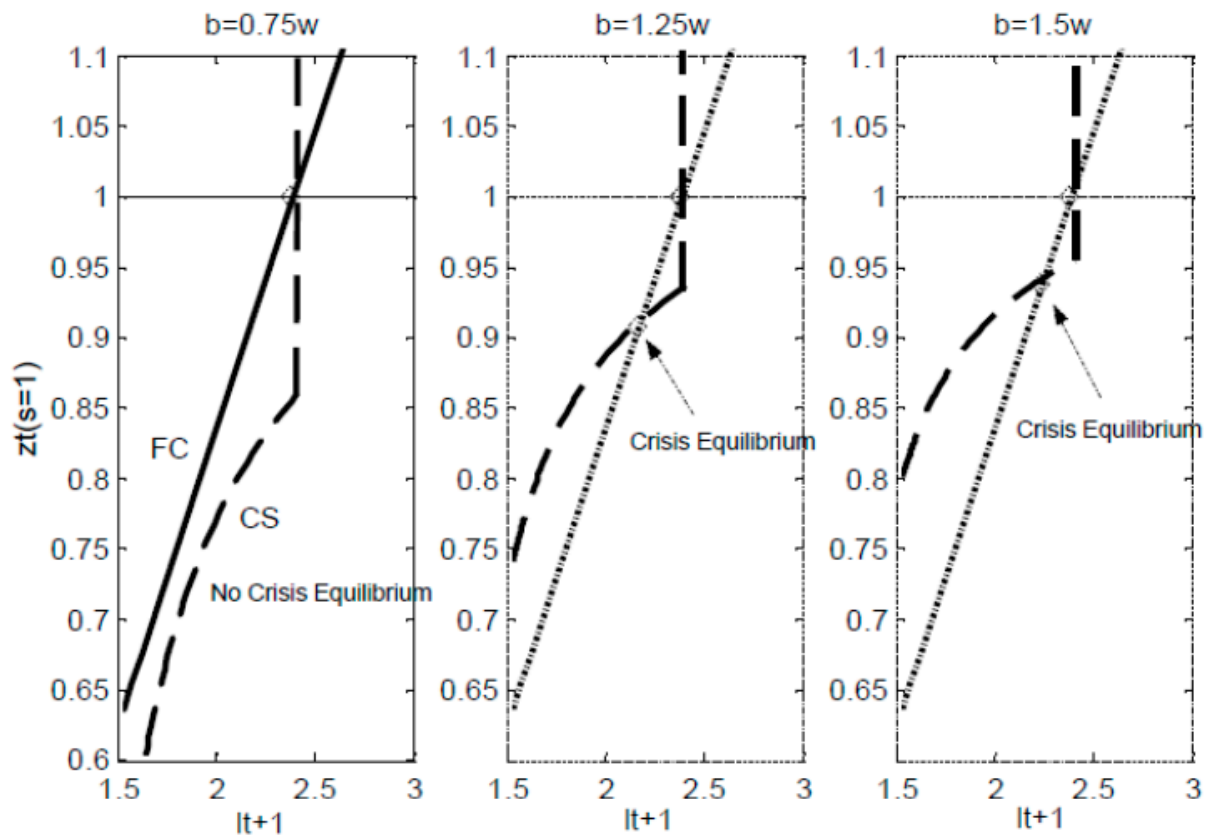

CInternational Monetary Fund. Not for Redistribution 
Figure 3. Probability of Crisis and Effect on Prices, Private Credit and Output

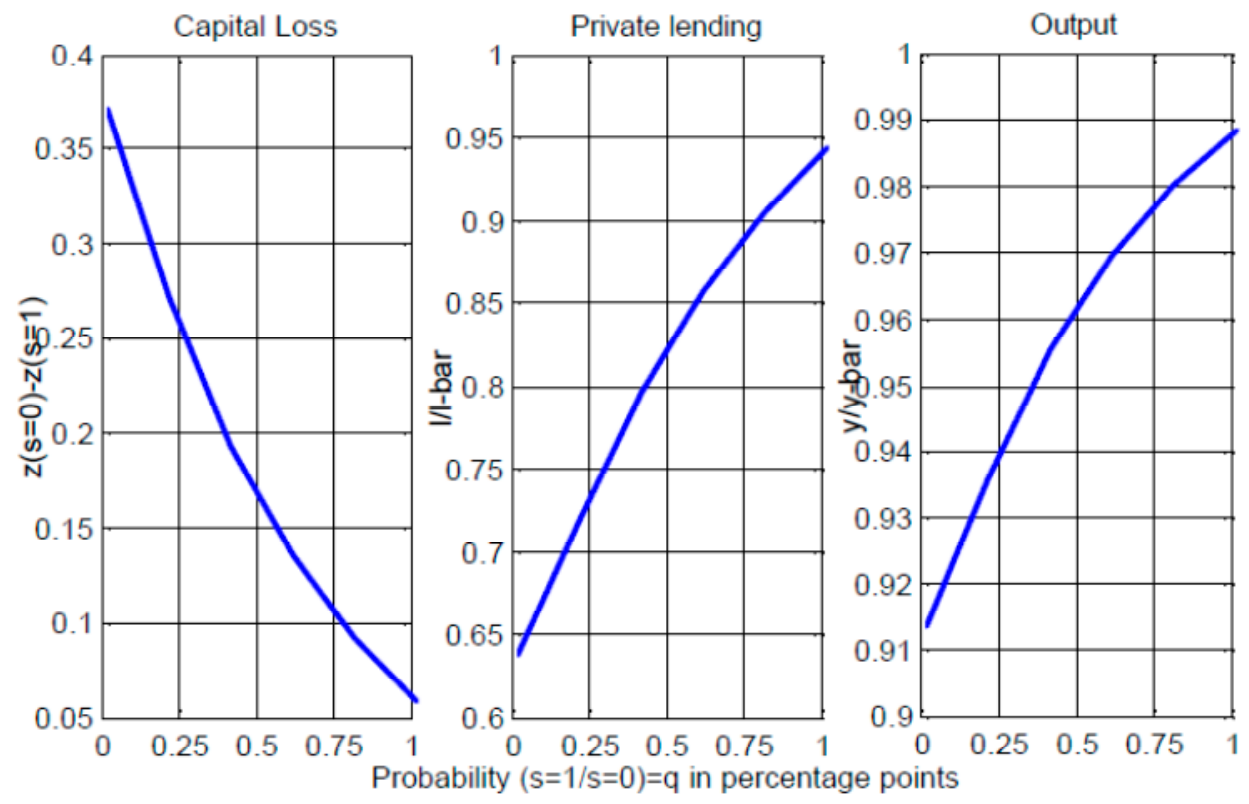




\section{Appendix}

Solution to Bank's Maximization Problem. The bank maximization problem can be written as the following dynamic programming problem:

$$
V(l, b, k, s)=\max _{l^{\prime}, k^{\prime}, b^{\prime}}\left\{\left[(z+x) b+l\left(1+r^{l}\right)+k(1+r)-l^{\prime}-k^{\prime}-z b^{\prime}\right]+\frac{E V\left(l^{\prime}, b^{\prime}, k^{\prime}, s^{\prime}\right)}{(1+r)}\right\}
$$

subject to:

$$
\begin{array}{rlrl}
l^{\prime}+k^{\prime}+z b^{\prime} & \leq z_{-1} b+l+k & (d \geq \pi) \\
(z+x) b+l\left(1+r^{l}\right)+k(1+r) & \geq l^{\prime}+k^{\prime}+z b^{\prime} \quad(d \geq 0) \\
-k & \leq \gamma\left[l^{\prime}+k^{\prime}+z b^{\prime}\right] \quad\left(-k \leq \gamma w^{b}\right) \\
A & =\left[\begin{array}{cc}
(1-q) & 0 \\
q & 1
\end{array}\right]
\end{array}
$$

The Kuhn-Tucker conditions of this problem are given by:

$$
\begin{aligned}
\eta & =\left[\frac{r^{l \prime}-r}{1+r}\right] E\left(1+\mu^{\prime}\right) \\
z & =\frac{E\left[\left(z^{\prime}+x^{\prime}\right)\left(1+\mu^{\prime}\right)\right]}{\left(1+r^{l \prime}\right) E\left(1+\mu^{\prime}\right)} \\
1+\mu+\lambda & =E\left(1+\lambda^{\prime}\right)\left[1+\frac{(1+\gamma)\left(r^{l \prime}-r\right)}{(1+r)}\right]+\frac{E\left(\mu^{\prime}\right)}{(1+r)} \\
\gamma\left[l^{\prime}+k^{\prime}+z b^{\prime}\right]+k & \geq 0 ; \eta \geq 0 \text { w.c.s. } \\
\left(d^{b}-\pi^{b}\right) & \geq 0 ; \mu \geq 0 \text { w.c.s. } \\
d^{b} & \geq 0 ; \lambda \geq 0 \text { w.c.s. }
\end{aligned}
$$

Since profits can be negative (the bank suffer a capital loss) only in the event of a bad stochastic bad shock, the constraint $d^{b} \geq 0$ can only bind at time $\mathrm{t}=\mathrm{T}$, defined as the time of a crisis. It follows that $\lambda_{t}=0$ for all $t \neq T$. On the other hand, the constraint $\left(d^{b} \geq \pi^{b}\right)$ cannot bind when $\pi^{b}<0$ and therefore $\mu_{T}=0$.

On the other hand, since after a bad realization uncertainty is resolved, it follows $\lambda_{t}=0$ for $t>T$. Then, solving difference equation (53) we can get an expression for $\lambda_{T}$ : 


$$
\lambda_{T}=\sum_{j=0}^{\infty}\left[\frac{(1+\gamma)\left(r_{T+j}^{l}-r\right)}{(1+r)^{j}}\right]
$$

Finally, we know that $\lambda_{t}=0$ and $\mu_{t} \geq 0$ for all $t<T$. Then, using (57) to solve equation (53) yields:

$$
\mu_{t}=E_{t} \sum_{j=1}^{\infty}\left[\frac{\lambda_{t+j}(s)}{(1+r)^{j-1}}\right]
$$

It follows that the first order conditions can be expressed as:

$$
\begin{aligned}
& {\left[\gamma w_{t}^{b}+k_{t}\right]\left[\frac{r_{t}^{l}-r}{(1+r)}\right]=0} \\
& d_{t}^{b}\left[\lambda_{t}\right]=0 \\
& {\left[d_{t}^{b}-\pi_{t}^{b}\right]\left[\mu_{t}\right]=0} \\
& \frac{E_{t}\left\{\left[z_{t+1}+x_{t+1}\right]\left[1+\lambda_{t+1}\right]\right\}}{\left(1+r_{t}^{l}\right) \cdot E_{t}\left\{\lambda_{t+1}\right\}}=z_{t} \\
& \lambda_{t}(s)=\left\{\begin{array}{cc}
0 & \text { if } t \neq T \\
\sum_{j=0}^{\infty}\left[\frac{(1+\gamma)\left(r_{t+j}^{l}-r\right)}{(1+r)^{j}}\right] & \text { if } t=T
\end{array}\right.
\end{aligned}
$$

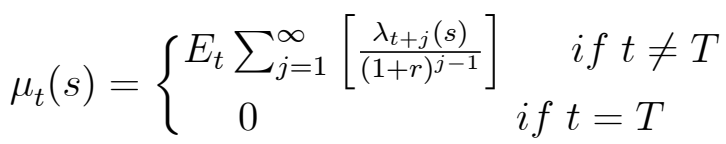

Proof of Proposition 1. Notice first that under a set of beliefs such that $z_{t}(s=0)=$ $z_{t}(s=1)$, equation (19) simplifies to $z_{t}=\frac{z_{t+1}+x_{t+1}}{\left(1+r_{t}^{l}\right)}$. Then, taking into account that $x t \leq r$ for all t,we can solve for this difference equation, which yields $z_{t}=\sum_{j=0}^{\infty}\left[\frac{x_{t}}{\prod_{i=0}^{j}\left(1+r_{t+i}^{l}\right)}\right] \leq$ $\sum_{j=0}^{\infty}\left[\frac{x_{t}}{\prod_{i=0}^{j}\left(1+r_{t+i}^{l}\right)}\right] \leq 1$. Also, as prices do not change with the state of nature, it is straight forward to show that banks cannot make negative profits in equilibrium ${ }^{16}$. Recall that banks' profits are given by: 


$$
\pi_{t}^{b}=\left[z_{t}+x_{t}-z_{t-1}(1+r)\right] b_{t-1}^{b}+l_{t-1}^{b}\left(r_{t-1}^{l}-r\right)+w_{t-1}^{b} r
$$

And since $z_{t}+x_{t} \geq z_{t-1}(1+r)$ and $r_{t-1}^{l} \geq r$, then the first two terms are nonnegative and therefore: $\pi_{t}^{b} \geq w_{t-1}^{b} r>0$. This implies that $d_{t}^{b}=\pi_{t}^{b} \geq 0$ and therefore banks 'net worth is constant over time $\left(w_{t}^{b}=w_{0}^{b}\right.$ for all $\left.t\right)$. Then, using assumption 1 we know that:

$$
b+z_{t} \bar{l} \leq b+\bar{l}<(1+\gamma) w_{0}^{b}=(1+\gamma) w_{t}^{b}
$$

It follows that the borrowing constraint does not bind at any point in time and therefore $r_{t}^{l}=r$ for all $t$. As a result output is at its maximum at all times $\left(y_{t}=\bar{y}\right)$ and so fiscal revenues $\left(\Gamma_{t}=\bar{\Gamma}\right.$ for all $\left.\mathrm{t}\right)$. This implies that there are no problems of debt sustainability; $x_{t}=r$ and $z_{t}=1$ for all $t$, which implies that agents beliefs are correct in equilibrium: $z_{t}(s=0)=z_{t}(s=1)=1$.

This is therefore a perfect foresight equilibrium with full employment and no problems of debt sustainability. In addition, since $z_{t}=\left[z_{t+1}+x_{t+1}\right] /(1+r)$ and $l_{t}=l_{t-1}=\bar{l}$ it follows that the resource constraint of the economy is given by:

$$
h_{t}=h_{t-1}(1+r)+f(\bar{l})-c_{t}
$$

Solving this equation recursively and imposing the transversality condition $\lim _{t \rightarrow \infty} \frac{h_{t}}{(1+r)^{t}}=$ 0 yields the intertemporal resource constraint:

$$
\sum_{t=0}^{\infty} \frac{c_{t}}{(1+r)^{t}}=h_{0}(1+r)+\sum_{t=0}^{\infty} \frac{f(\bar{l})}{(1+r)^{t}}
$$

Finally, using equation (4) and (30), follows that the consumption path is given by:

$$
c_{t}=r h_{0}+\left[\frac{r}{\sigma}\right]^{\frac{1}{\sigma-1}} \quad \text { for all } t
$$

Proof of Proposition 2. We start this proof by showing that $\operatorname{cov}\left(z_{t+1}+x_{t+1}, 1+\lambda_{t+1}\right)$ and therefore the risk premium is positive: from equation(20) and the fact that the economy jumps to a new steady state after a crisis we know:

$$
\lambda_{t+1}(s)= \begin{cases}0 & \text { if } t \neq T \\ \frac{(1+r)(1+\gamma)\left(r_{t+1}^{l}-r\right)}{r} & \text { if } t=T\end{cases}
$$


Then if $\lambda_{t+1}(s)>0$ it follows that $r_{t+1}^{l}>r$ and from equation (16) we know:

$$
-k_{t+1}=\gamma w_{t+1}^{b}
$$

We know that for a crisis to occur at time $t+1$ it must be the case that $\pi_{t+1}^{b}<0$ (otherwise $w_{t+1}^{b}=w_{t}^{b}$ and so a crisis should have occurred before or not occurred at all). The we know that:

$$
w_{t+1}^{b}=w_{t}^{b}+\pi_{t+1}^{b}
$$

Combining (71) and (72) yields:

$$
l_{t+1}+z_{t+1} b=\left\{w_{t}^{b}(1+r)+\left[z_{t+1}+x_{t+1}-z_{t}(1+r)\right] b+l_{t}\left(r_{t}^{l}-r\right)\right\}(1+\gamma)
$$

from which follows that if $\frac{d x_{t+1}}{d z_{t+1}}>0$ which is the case for normal parameters, then $\frac{d \lambda_{t+1}}{d z_{t+1}}<0$ if $t+1=T$.

Then, from this previous result and equation (70) it follows that: $\operatorname{cov}\left(z_{t+1}+x_{t+1}, 1+\right.$ $\left.\lambda_{t+1}\right)<0$. This proves the first part of the proposition. To prove the second part, we prove first that $z_{t+1}(s=0)+x_{t+1}(s=0)>z_{t}(1+r)$ by contradiction:

Assume :

$$
z_{t+1}(s=0)+x_{t+1}(s=0)<z_{t}(1+r)
$$

Then since $z_{t+1}(s=1)+x_{t+1}(s=1)<z_{t+1}(s=0)+x_{t+1}(s=0)$ by assumption, it follows that it must be the case that:

$$
z_{t+1}(s=1)+x_{t+1}(s=1)<z_{t}(1+r)
$$

Combining (74) and (75) we know that:

$$
E\left[z_{t+1}+x_{t+1}\right]<\frac{E\left\{\left[z_{t+1}+x_{t+1}\right]\left[1+\lambda_{t+1}\right]\right\}(1+r)}{\left(1+r_{t}^{l}\right)} \leq E\left\{\left[z_{t+1}+x_{t+1}\right]\left[1+\lambda_{t+1}\right]\right\}
$$

Using equation (21) and the fact that $r_{t}^{l} \geq r$ implies:

$$
E\left[z_{t+1}+x_{t+1}\right]<E\left\{\left[z_{t+1}+x_{t+1}\right]\left[1+\lambda_{t+1}\right]\right\}
$$

Rearranging and using the fact that $\operatorname{cov}(x, y)=E(x y)-E(x) E(y)$, yields:

$$
-\operatorname{cov}\left[z_{t+1}+x_{t+1}, 1+\lambda_{t+1}\right]<0
$$

which contradicts the result proven before. It follows therefore that it must be the 
case that $z_{t+1}(s=0)+x_{t+1}(s=0)>z_{t}(1+r)$.

Then, it follows that:

$$
\pi_{t+1}^{b}(s=0)=w_{t}^{b} r+\left[z_{t+1}(s=0)+x_{t+1}(s=0)-z_{t}(1+r)\right] b+l_{t}\left(r_{t}^{l}-r\right)>0
$$

and so:

$$
w_{t+1}^{b}=w_{t}^{b} \quad \text { for all } t>T-1
$$

Finally notice that since $z_{t} \leq 1$, then $\bar{l}+z_{t} b \leq \bar{l}+b$. And from assumption 1 we know that $\bar{l}+b<(1+\gamma) w_{0}^{b}$. It immediately follows that:

$$
\bar{l}+z_{t} b \leq \bar{l}+b<(1+\gamma) w_{0}^{b}
$$

and therefore the borrowing constraint does not bind for $t<T$. From equation (16) follows that $r_{t}^{l}=r$ and therefore $y_{t}=\bar{y}$ for all $t<T$.

Proof of Proposition 3. To prove this proposition we use figure 1. Notice first that since $z_{T-1} \leq 1$, then evaluating the credit supply (CS) schedule at $z_{T}=1$ we get:

$$
l_{T+1}=(1+\gamma)\left[(1+r)\left(1-z_{T-1}\right] b+(1+\gamma) w_{0}^{b}(1+r)>(1+\gamma) w_{0}^{b}\right.
$$

and using assumption 1 we have:

$$
l_{T+1}+b>(1+\gamma) w_{0}^{b}>\bar{l}+b
$$

It follows therefore that $l_{T+1}>\bar{l}$ when evaluating the CS schedule at $z_{T}=1$. This implies that the CS schedule crosses the $\bar{l}$ line in figure 1 before for some value of $z_{T}<1$. It follows therefore that the CS and the FC schedule cross for some $z_{T} \in[0,1)$ if and only if the CS schedule crosses the vertical axis below zero. That is, a necessary and sufficient condition for a crisis equilibrium to exist $\left(z_{T} \in[0,1)\right)$ is given by:

$$
(1+\gamma)\left[(1+r)\left(w_{0}^{b}-z_{T-1} b\right)+r b\right]<0
$$

which can be rearranged as:

$$
b>\frac{(1+r) w_{0}^{b}}{z_{T-1}(1+r)-r}
$$

proving proposition 3. 


\section{References}

[1] Allen, G.A., 1990, "The market for information and the origin of financial intermediation," Journal of Financial Intermediation.

[2] Arellano, C., J.C. Conesa and T.J. Kehoe, 2012, "Chronic Sovereign Debt Crises in the Eurozone, 2010-2012", Federal Reserve Bank of Minneapolis Policy Paper $12-4$.

[3] Bevilaqua, A. and M. Garcia 1999, "Banks, Domestic Debt Intermediation and Confidence Crises: The Recent Brazilean Experience," mimeo, (PUC-RIO).

[4] Buiter, W. ,1987, "Borrowing to Defend the Exchange Rate".

[5] Burnside, C., Eichenbaum, and S. Rebelo, 2003, "Government Financing in the Wake of Currency Crises," mimeo.

[6] Catao, L. and N. Sutton, 2002, "Sovereign Defaults: The Role of Volatility," IMF WP 02/149.

[7] Catena, M.., 1996, "Banking crises and monetary policy in Argentina," mimeo UCLA.

[8] Conesa, J.C. and T. Kehoe, 2012, "Gambling for Redemption and Self-Fulfilling Debt Crises," Federal Bank of Minneapolis Staff Report 465.

[9] De la Torre, A., E. Levy Yeyati and S. Schmukler, 2002, "Argentina's Financial Crisis: Floating Money, Sinking Banking," mimeo World Bank.

[10] Diamond, D., 1984, "Financial Intermediation and Delegated Monitoring," Review of Economic Studies.

[11] Druck, P., 2000, "Effect of government policy on the banking system," UCLA doctoral dissertation.

[12] Eichengreen, B. 2001, "Crisis prevention and Management: Any New Lessons from Argentina and Turkey?," mimeo.

[13] Flood, R., P. Garber, and C. Kramer, 1996, "Collapsing Exchange-Rate Regimes: Another Linear Example," Journal of International Economics 41, 223-234.

[14] Kalemli-Ozcan, S., E.Papaioannou, and F. Perri, 2011, "Global Banks and Crisis Transmission," Working Paper, University of Houston. 
[15] Kamber, G. and C. Thonissen, 2012, "Financial Intermediation and the International Business Cycle: The Case of Small Countries with Large Banks," Working Paper, Reserve Bank of New Zealand.

[16] Kharas, H. ; B. Pinto, and S. Ulatov, 2001, "An Analysis of the Russia's 1998 Meltdown: Fundamentals and Market Signals," Brooking Papers on Economic Activity.

[17] Kollmann, R., Z. Enders and G. Muller, 2011, "Global Banking and International Business Cycles," European Economic Review 55, 407-426.

[18] Leland, H. and D. H. Pyle, 1977, "Informational asymmetries, financial structure and financial intermediation," The Journal of Finance.

[19] Mendoza, E. and V. Quadrini, 2010, "Financial Globalization, Financial Crisis and Contagion," Journal of Monetary Economics 57, 24-39.

[20] Perry, G. and L. Serven, 2002, "The Anatomy of a Multiple Crisis: Why was Argentina special and what can we learn from it?," mimeo World Bank.

[21] Rodriguez, C. , 1992, "Financial reforms in Latin America: The cases of Argentina, Chile and Uruguay," CEMA DT \#84.

[22] Rojas-Suarez, L. and S.R. Weisbrod, 1994, "Financial market fragilities in Latin America: from banking crises resolution to current policy challenges," IMF WP $94 / 117$.

[23] Sturzenegger, F. ,2002, "Default episodes in the 90s: factbook and preliminary lessons," mimeo UTDT.

[24] Ueda, K., 2012, "Banking Globalization and International Business Cycles: Crossborder Chained Credit Contracts and Financial Accelerators,' Journal of International Economics 86, 1-16. 